\title{
TRADITIONAL VALUES AND THEIR ADAPTATION IN SOCIAL HOUSING DESIGN: TOWARDS A NEW TYPOLOGY AND ESTABLISHMENT OF 'AIR HOUSE' STANDARD IN MALAYSIA
}

\author{
Mohd Firrdhaus Mohd Sahabuddin* and Cristina Gonzalez-Longo** \\ *School of Arts, Culture and Environment (ACE), The University of Edinburgh, United Kingdom \\ **Department of Architecture, University of Strathclyde, Glasgow, United Kingdom \\ dosh212@gmail.com, c.gonzalez-longo@strath.ac.uk
}

\begin{abstract}
Large migration from rural areas to urban areas like Kuala Lumpur has led to some implications for economic, social and cultural development. This high population has placed enormous demand on the existing housing stocks, especially for low-income groups. However, some issues arise, one of which is overheated indoor air temperature. This problem contributes to the high-energy usage that forces huge sums of money to be spent on cooling the house by using mechanical equipment. Therefore, this study focuses on thermal comfort in social housing, and incorporates traditional values into its design to achieve a certain measurement of natural ventilation in a house. From the study, the carbon emission and energy consumption for an air-conditioned house is $67 \%, 66 \%$ higher than a naturally ventilated house. Therefore, this research has come up with a new typology design, which has a large exposed wall area and full-length openings on the opposite walls to increase cross ventilation. At the end of this research, the measurement of thermal comfort for a naturally ventilated building called 'Air House' has been identified.
\end{abstract}

Keywords: Vernacular Architecture; Traditional Malay House; Air House; Sustainable Design; Social Housing; Malaysia

\section{INTRODUCTION}

Malaysia is located in Southeast Asia and is one of the fastest developing countries in the world. United Nations calculations have projected a dramatic urban future for this region (Salih 1982). The patterns of urbanization in Southeast Asia's top cities are expected to increase rapidly.

Kuala Lumpur, as a capital city of a developing nation, plays a significant role in the urbanization and development of the country. The city's population grew from about 0.32 million in 1957 to almost 1.62 million in 2006 (Mohit, et al., 2010). Based on this situation, Malaysia was expected to require about 709,400 new housing units between 2006 and 2010 (UN-HABITAT, 2011). The other problem that has arisen is the increasing number of squatters and slum areas. Social housing schemes such as People's Housing Project (PHP) have been one of the approaches undertaken by the government to solve this problem. However, the issue of thermal comfort and space design in social housing is always a hot topic as it is not compatible with the living patterns of Malaysian society.

The low-income population that occupy the majority of social houses cannot afford to install and maintain an air-conditioning system in their homes. The system leads towards environmental pollution and energy waste. Therefore, one of the precedent studies is the traditional Malay house that has touted the advantages of maintaining the internal comfort level by natural and passive approaches.

The aims of this research are to seek the appropriate design methods in social housing that can achieve the right thermal comfort by using passive approaches. Thermal comfort is very important, not only for enhancing the quality of indoor living, but also because it can help to reduce carbon emission and energy consumption. At present, the thermal comfort conditions have been set up for indoor space designed with an air-conditioning system. Therefore, this 
research tries to find the best description of thermal comfort conditions for a naturally ventilated space that suits Malaysia's environment and comfort zone.

\section{MALAYSIAN VERNACULAR ARCHITECTURE AND ITS RELATIONSHIP TO CLIMATE Vernacular Architecture of Traditional Malay House}

The construction elements in Malay vernacular architecture are light timber-framed structures, forming elevated floors, sloping long roofs with large overhangs, louvered windows, timber or woven bamboo walls and screenings (on the upper walls). In terms of spatial elements, the basic spaces of the serambi, rumah ibu and dapur are the most common in a traditional Malay house (Figure 1). Although these houses have variations, elements such as spatial, functional and physical could be determined as the most common among them (Ismail \& Ahmad, 2006).

The traditional Malay house can be divided into front and back sections, which are centred around the rumah ibu (the core house) and the dapur (kitchen) respectively (Yuan, 1987: 34). The serambi, in any event, will be at the front, followed by the rumah ibu and dapur. This arrangement is similar in all Malay houses and closely reflects the social interaction in Malay communities. Table 1 shows the common uses and privacy levels of interior spaces in a traditional Malay house.

Table 1: The uses and privacy levels of spaces in a typical traditional Malay house

(Source: Authors)

\begin{tabular}{|l|l|l|}
\hline \multicolumn{1}{|c|}{ Elements } & \multicolumn{1}{c|}{ Activities } & \multicolumn{1}{c|}{ Privacy Level } \\
\hline $\begin{array}{l}\text { Serambi / Anjung } \\
\text { Veranda / Porch }\end{array}$ & $\begin{array}{l}\text { Male entrance, relaxing, } \\
\text { child monitoring, greet } \\
\text { and treat space for } \\
\text { guests }\end{array}$ & Public space \\
\hline $\begin{array}{l}\text { Rumah Ibu } \\
\text { (The Main House) }\end{array}$ & $\begin{array}{l}\text { Meeting, praying, } \\
\text { reading/reciting, sleeping } \\
\text { (at night) }\end{array}$ & $\begin{array}{l}\text { Semi private and } \\
\text { private space }\end{array}$ \\
\hline $\begin{array}{l}\text { Dapur } \\
\text { (Kitchen) }\end{array}$ & $\begin{array}{l}\text { Cooking, preparing foods, } \\
\text { dining, washing }\end{array}$ & Private space \\
\hline $\begin{array}{l}\text { Kolong } \\
\text { (Space underneath } \\
\text { the house) }\end{array}$ & $\begin{array}{l}\text { Storing, working, } \\
\text { repairing, drying clothes } \\
\text { (rainy season) }\end{array}$ & Public space \\
\hline
\end{tabular}

The serambi is the smallest space among the other spaces. In some cases of the twelvecolumn house, this space usually accommodates a quarter of the house, and the floor level will always be lower than the rumah ibu floor level. The form of the serambi is usually rectangle and in some cases is an extraordinarily long narrow space (Chen, et al., 2008).

This area can be constructed with or without perimeter walls; however, it tends to look like a semi-outdoor space with numerous daylighting from the openings. Figure 2 shows the location of serambi space in two examples of Malay houses. The serambi in the house of Andak Endah has no walls, while the other serambi in the house of Tan Mas Mohar is built with walls.

The importance of the serambi is to serve as the first greeting space for guests after entering the house (Yuan, 1987). In a traditional Malay kampong, houses are built in random positions but can be seen from the distance. The serambi in this case will be the place for social interaction within the neighbourhood, and for parents to monitor their children playing in the yard.

The rumah ibu is the core space of the Malay house. This has the largest area, highest floor level and highest roof level (Yuan, 1987: 37). In respect of the needs and privacy of family members, bedrooms are provided, but the number is flexible and depends on family size (Figure 2). Lighting in this space is reduced to provide coolness. (Yuan, 1987). 
The rumah ibu is usually used for official events and a place for treating well-known guests or close relatives. Official ceremonies relating to customs are also carried out here. These include engagement, marriage and wedding ceremony. On normal days, this space will be for relaxing, reading, mingling with other family members, and for use as a sleeping area at night (Chen, et al., 2008).

The kitchen, or dapur, is always situated at the back of the house (Yuan, 1987: 38). The functions of this space are for cooking, washing and eating. The basic layout of a Malay house will include a dapur within the rumah ibu, but in some cases the dapur will be connected with a pelantar, a roofless platform, or a selang. This, on the other hand, is an enclosed space that serves as a walkway and used as a second entrance for females during a ceremony (Figure 2). Although the dapur is the last space in the house, it holds the prestigious function of family gatherings where dining takes place together with other family members. Therefore, the dapur has a large space, which is considered the second largest in a Malay house.

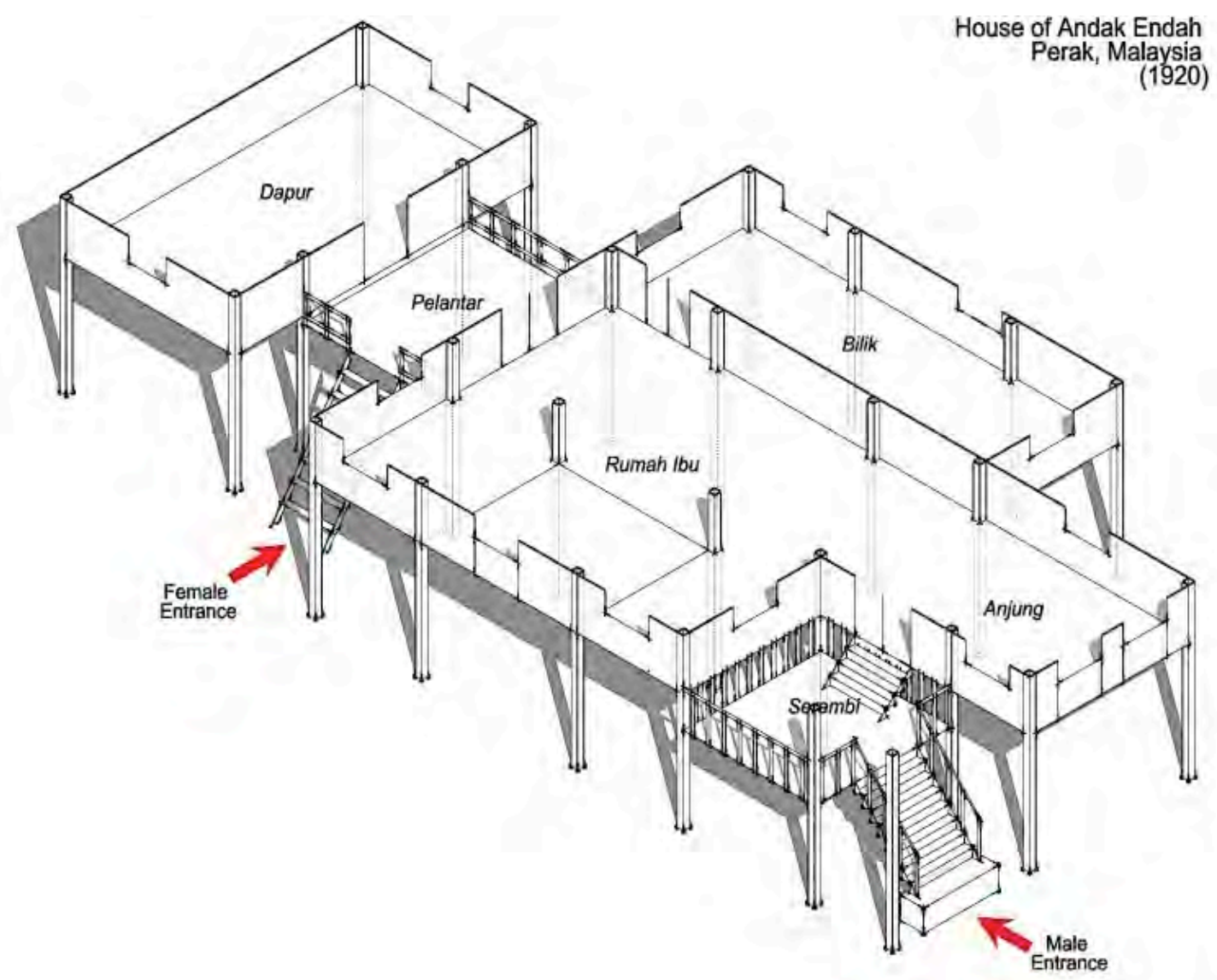

Figure 1. The internal layout of Andak Endah House, 1920 (Source: Authors) 

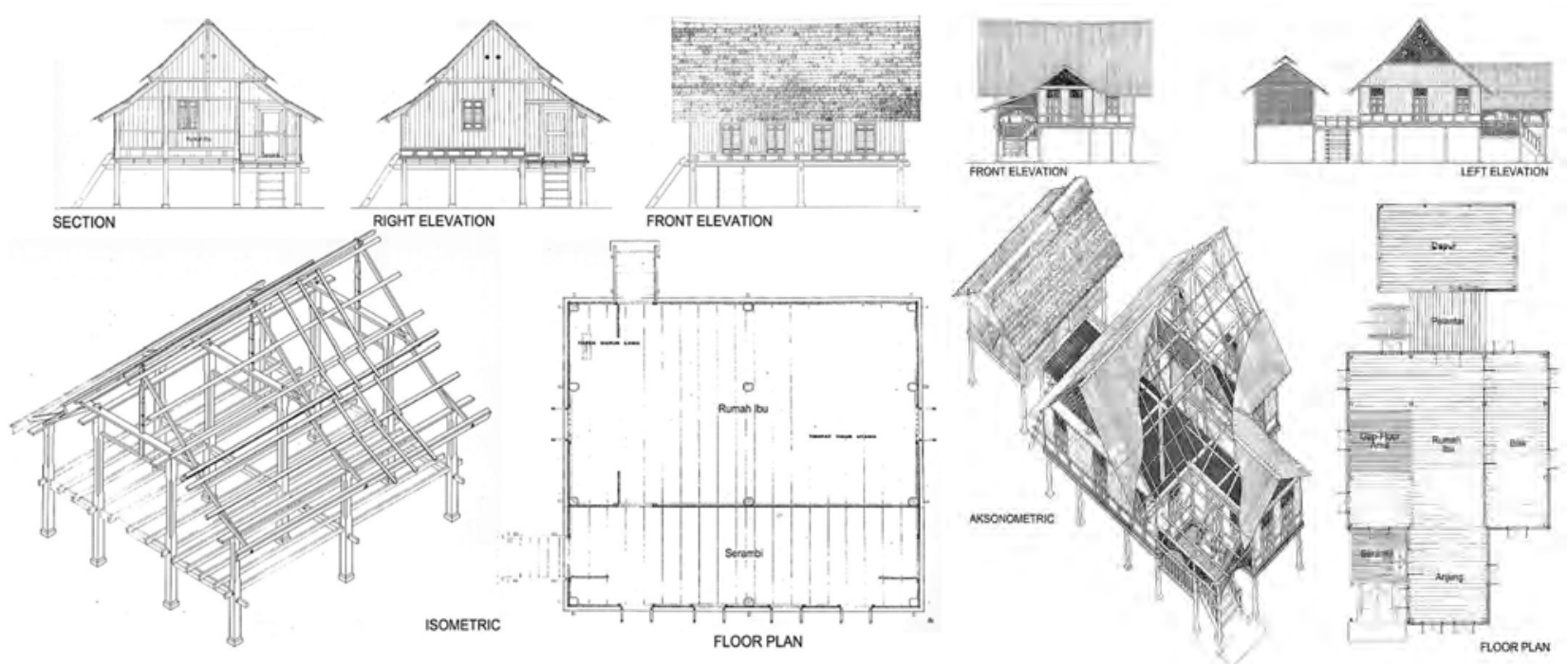

Figure 2. House of Datuk Baginda Tan Mas Mohar (1850) and Andak Endah (1920)

(Source: KALAM, 1986 \& 1996)

\section{Adapting to the Climate}

The uniqueness of a Malay house is that it is built on stilts. This approach in many ways has several benefits from a thermal, functional and safety point of view. The raised floor, which is built higher than the ground, can catch winds of a higher velocity (Yuan, 1987: 71), and the use of timber planks for the floor, which have gaps between them, can bring the air to the inner space. Hanafi (1994) suggests that moist ground requires more sunlight to dry, and a raised floor is one of the solutions. The wet climate does not just make the ground damp but can also cause floods. Therefore, stilt heights vary between Malay houses located in the northern and southern regions.

Several research findings about stilt heights in traditional Malay houses have proved those in the northern region have more height than those in the southern region (Figure 3). The underneath space allocated by the raised floor can provide shelter for the livestock, working space, and a clothes-drying area during rainy seasons.

A traditional Malay house allows ventilation by having many full-length windows and doors at body level (Yuan, 1987: 76). Hassan and Ramli (2010) conclude that the large number of windows and openings aided by ornamentation at the perimeter walls can contribute to the cross ventilation process (Figure 3). However, further analysis by the same authors (2010) reveals that large openings on Malay house walls create high air intakes outside to reduce the performance of the stack effect.

Roof space in a traditional Malay house is properly ventilated by the provision of ventilation joints and panels in the roof construction (Yuan, 1987: 75). As one of the indigenous materials, the attap roof used in Malay houses has a low thermal capacity. This material does not retain heat and cools immediately. Another climatic responsive design of a double-slope roof is its gable ends. Having various motive designs, this component also has ventilation panels which allow air to flow into the roof space and cool the house (Yuan, 1987:111).

From the two examples in Figure 3, the roof overhangs in the Andak Endah house range from $1000 \mathrm{~mm}$ to $1500 \mathrm{~mm}$, and the Datuk Baginda Tan Mas Mohar house has overhangs ranging from $1400 \mathrm{~mm}$ to $1600 \mathrm{~mm}$. Large overhangs and the low exposed vertical areas (windows and walls) in a traditional Malay house provide good protection against driving rain, good shading, and allow the windows to be left open most of the time for ventilation (Yuan, 1987). Meanwhile, the roof angle for both cases ranges from $30^{\circ}$ to $60^{\circ}$. The steep roof angle is used to quickly drain 
off any rain falling onto the roof surface before it seeps through the layers of thatching (Lee, 2003:251).

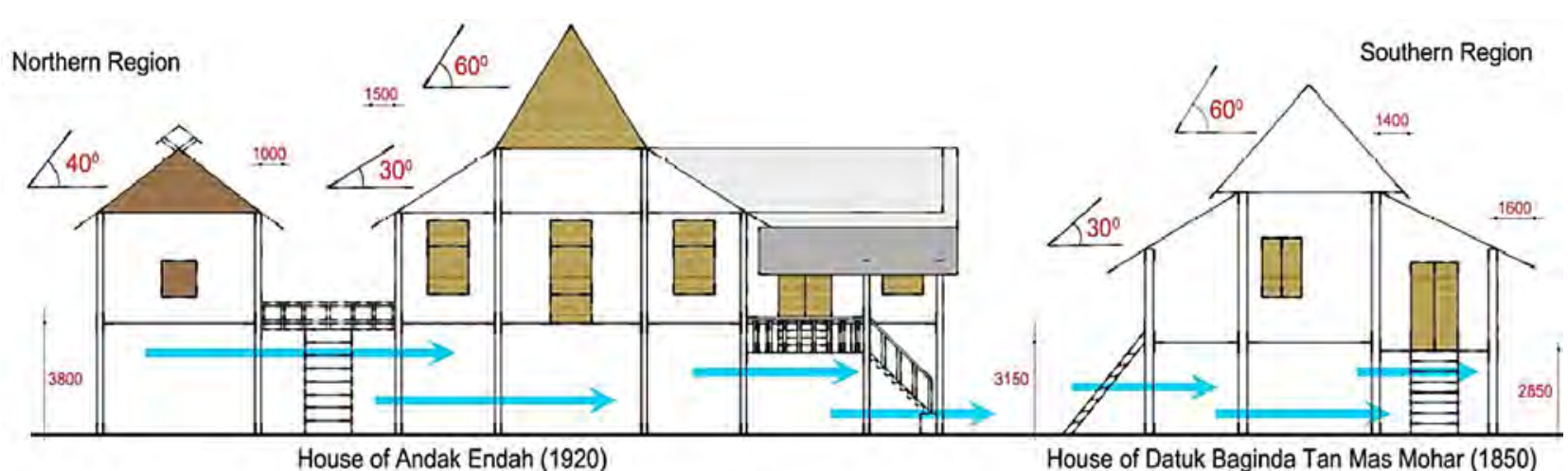

Figure 3. The difference of stilt height and roof angle in traditional Malay houses at northern and southern region of Malaysia (Source: Authors)

\section{Architectural And Construction Issues of People's Housing Project (PHP) Schemes}

Malaysia is one of the developing countries experiencing a highly rapid urban growth. This situation has led to large migration from rural to urban areas, and resulted in the existence of slums and squatter areas. Social housing such as the People's Housing Project Scheme (PHP) is one of the initiatives by the government to solve this problem. The National Housing Department of Malaysia (JPN) has a standardized social housing design in Malaysia to ensure that the basic requirements of providing adequate accommodation for low-income families are achieved. Figure 4 shows the design of a unit of PHP 2000. The size for the unit is 130 square feet per person (JPN, 2006) or 650 square feet in total (60.38 square metres). This figure is for an average family member of 5 persons per unit (Goh \& Ahmad, 2011). As the demand is very high, hundreds of thousands of PHP schemes have been built since 1998. However, the PHP design has received a lot of criticism for its insufficient space size and location.

Amongst the architectural issues reflected from the PHP design is the lack of a storage area. Therefore, the majority of residents placed their goods in front of their house; this affects the efficiency of a corridor as a safety route. The main door unit located abutting the corridor without any recess reduces the opportunity of neighbourhood interaction. Meanwhile, the small size and deep location of the kitchen and yard restricts its functions. The orientation of unit layout that has a minimum external wall area minimizes openings and air movement. The internal layout of the PHP 2000 that has complicated partitions reduces cross ventilation. Furthermore, openings such as aluminium casement windows without top louvers does not allow air movement to enter the indoor space.

On the other hand, the insufficient location of the bathroom and bedroom doors reduces the privacy level of residents. In the PHP design, the toilet and bathroom areas are separated, meaning a restriction in air and people movement in these spaces.

Furthermore, heavyweight materials with a high heat storage capacity are not suitable to a warm-humid climate like Malaysia. These materials take a considerable time to heat, then once heated take a long time to cool down again (Saini, 1970). Thus, lightweight materials that have a low heat storage capacity should be observed and replaced by conventional materials. In conjunction with that, prefabricated construction methods could be implemented in PHP 2000 to make it flexible in terms of internal space layout. 


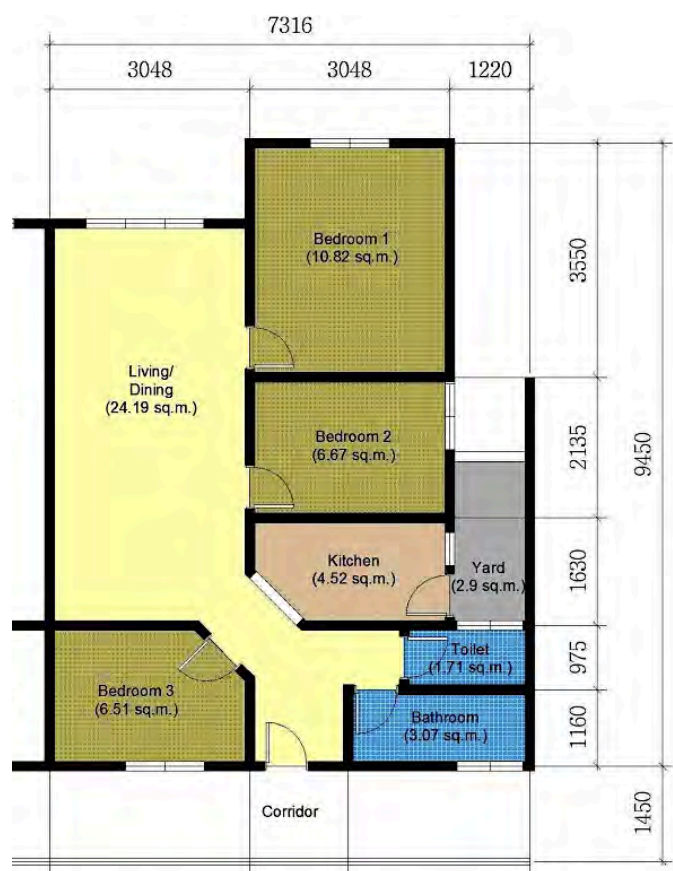

Figure 4. Layout plan of a PHP 2000 (Source: Redraw by the author from Goh \& Ahmad, 2011)

Materially, brick wall and post and beam concrete are the most common construction methods for social housing in Malaysia, largely due to these materials being cheap and easily available. Brick construction has a low u-value of $1.96 \mathrm{wm} 2{ }^{\circ} \mathrm{C}$, though it has an eight-hour time lag, which has an adverse effect on the internal environment, especially at night (Hanafi, 1994).

Saini (1970) suggested that in a warm-humid region, heavyweight construction is at a disadvantage since the cooling process at night is so slow that the indoor temperature is kept too high for a comfortable sleep. Therefore, materials with a high heat storage capacity, such as brick, concrete and stone, have no advantage in Malaysia's climate.

In addition, the residents of PHP flats agreed that the adjustable louvered windows are better for air movement compared with aluminium casement windows (Goh \& Ahmad, 2011).

Recently, the shortage of construction labour means prefabricated panels and frames have been used widely. In 1988 the Malaysian Government began efforts to persuade the construction industry in Malaysia to engage with a more systematic approach, such as an Industrialized Building System (IBS), in building construction (Abd. Rahman \& Omar, 2006). Besides the aims to reduce the dependency on foreign labour, an IBS construction method can also contribute to reducing construction periods and pollution of the environment.

\section{CASE STUDIES ANALYSIS}

\section{Case Studies Background}

Three case studies have been selected, two of which are traditional Malay houses, and the other a social house from the People's Housing Project Scheme (PHP 2000). The Malay houses selected are the house of Datuk Baginda Tan Mas Mohar and the house of Andak Endah. The houses are located in two different areas; the house of Datuk Baginda Tan Mas Mohar in the Negeri Sembilan state (southern region) and the house of Andak Endah in Perak state (northern region).

The house of Datuk Baginda Tan Mas Mohar, built in 1850, and the house of Andak Endah, built in 1920, have been chosen as typology houses and represent two different forms. The house of Datuk Baginda Tan Mas Mohar has a basic twelve-column structure, while Andak Endah has an expanded twelve-column structure. Social housing in Malaysia has been 
standardized, so using the People's Housing Project (PHP) as the third case study is quite reasonable.

Table 2 shows the total external wall area and its opening areas percentage. The Datuk Baginda Tan Mas Mohar house has 16.5\% opening areas and the house of Andak Endah has $17.9 \%$ opening areas. Meanwhile, PHP 2000 has only $8.9 \%$ opening areas. The size and location of opening areas are two key factors that can allow air to enter the building sufficiently. The two cases of Malay houses have larger opening areas compared to PHP 2000.

Table 2: Total external wall areas and opening areas in all case studies (Source: Authors)

\begin{tabular}{|c|c|c|c|c|}
\hline Case Studies & $\begin{array}{c}\text { Location of } \\
\text { Simulation }\end{array}$ & $\begin{array}{c}\text { External Wall } \\
\text { Areas } \mathbf{( m}^{\mathbf{2}} \mathbf{)}\end{array}$ & $\begin{array}{c}\text { External Opening } \\
\text { Areas } \mathbf{( m}^{\mathbf{2}} \mathbf{)}\end{array}$ & $\begin{array}{c}\text { Percentage } \\
\mathbf{( \% )}\end{array}$ \\
\hline $\begin{array}{c}\text { House of Tan } \\
\text { Mas Mohar }\end{array}$ & $\begin{array}{c}\text { Kuala Lumpur / } \\
\text { Subang }\end{array}$ & 485.9 & 80.0 & 16.5 \\
\hline $\begin{array}{c}\text { House of Andak } \\
\text { Endah }\end{array}$ & $\begin{array}{c}\text { Kuala Lumpur / } \\
\text { Subang }\end{array}$ & 259.0 & 46.4 & 17.9 \\
\hline $\begin{array}{c}\text { A Unit of PHP } \\
2000\end{array}$ & $\begin{array}{c}\text { Kuala Lumpur / } \\
\text { Subang }\end{array}$ & 117.4 & 10.5 & 8.9 \\
\hline
\end{tabular}

\section{Simulation's Design Settings}

The selection of the 6.4 version of the Integrated Environmental Solutions Software (also known as (IES <VE >) is due to its suitability towards the aims of the study, which is to simulate air temperature, relative humidity and air flow rate. For natural ventilation, MacroFlo, integrated into the IES simulation, is used to simulate airflow driven by wind pressure and buoyancy forces through elements such as windows, doors and openings. The simulation of MacroFlo runs from within Apache, which also simulates the indoor air temperature and relative humidity based on the ASHRAE design weather database. Meanwhile, MicroFlo uses a Computational Fluid Dynamic (CFD) to measure fluid flow and heat transfer processes around building spaces, which include the effects of climate (IES, 2012).

In this study, the simulation's location database is Kuala Lumpur/Subang weather with the latitude $3^{0} 12^{\prime}$ North and longitude $101^{\circ} 55^{\prime}$ East. The sea level height is 8 metres with the mean dry-bulb temperature 36.4 and wet-bulb temperature $16.1^{\circ} \mathrm{C}$. No HVAC system is applied, while east-west orientation is used in all simulation models. The openings of all samples assigned as window/door side hung with opening angle is 900, and opening hours range from 08:00 am to 10:00 pm. All the external walls are categorized as exposed walls without any obstacles.

According to Saini (1970), air temperature, relative humidity and air movement are the elements of climate which affect the comfort and well-being of the people. These factors also have complex inter-relationships between them, and, to a degree, each affects the other. Therefore, in this study, these three elements will be measured in detail, as well as carbon emission and energy consumption.

\section{Simulation's Results}

From the simulation's analysis, it can be deduced that the air temperatures in PHP 2000 and Malay houses show no significant difference within each other. The mean air temperatures obtained are within the comfort levels of 25.0 to $28.0{ }^{\circ} \mathrm{C}$. However the relative humidity results are higher than their suggested level of $30 \%$ to $60 \%$. Even though the relative humidity is high, there is only a small change in the air temperature. A change from 25 to $75 \%$ of relative humidity is predicted to move the temperature by only $1^{\circ} \mathrm{C}$ (Fisk, 1981).

The crucial finding obtained from the simulation is the air movement. Air movement in this scenario is very important because it can encourage heat loss through the evaporation process. 
Low air movement does little to generate a body's heat loss. Furthermore, Fisk (1981) suggested that air movement of about $150.0 \mathrm{l} / \mathrm{s}(0.15 \mathrm{~m} / \mathrm{s})$ or greater tends to increase air temperature and a body's heat loss. In conclusion, a traditional Malay house that has high air ventilation movement in and out has the better shelter and can provide more comfort to the human body than PHP 2000.

Table 3 shows the comparison of carbon emission and energy consumption for two different PHP 2000s. One unit uses an air conditioning system, the other is fully naturally ventilated. Both carbon emission and energy consumption for the PHP 2000 with an air conditioning system are higher than the PHP 2000 that uses natural ventilation. The carbon emission and energy consumption for the air-conditioned house is $67 \%$ and $66 \%$ higher than the naturally-ventilated house.

The huge gaps here show that it is worth encouraging people to use natural ventilation methods rather than an air conditioning system. Malay houses, for instance, can best describe the concept of a naturally ventilated house. Therefore, some elements, such as the size of openings and their placement, can be forwarded to a detailed level.

Table 3: Comparison of carbon emission and energy consumption of PHP units (Source: Authors)

\begin{tabular}{|c|c|c|}
\hline Variables & $\begin{array}{c}\text { PHP 2000 } \\
\text { (With Air Conditioning System) }\end{array}$ & $\begin{array}{c}\text { PHP 2000 } \\
\text { (Naturally Ventilated) }\end{array}$ \\
\hline Carbon Emission (KgCO $/$ Year) & 18,308 & 5,967 \\
\hline Energy Consumption (MWh/Year) & 20.20 & 6.8 \\
\hline
\end{tabular}

\section{TOWARDS A NEW TYPOLOGY OF SOCIAL HOUSING DESIGN AND THE ESTABLISHMENT OF 'AIR HOUSE' STANDARD IN MALAYSIA \\ Theoretical Model of A New Social Housing}

A theoretical model (TM) has been developed as an initiator towards sustainable social housing in Malaysia. The model design is a reflection of the design issues found in PHP 2000 that were discussed before. The issues of space sizes, internal circulation, cross ventilation and numbers of openings in PHP 2000 have been taken into consideration. PHP 2000 and TM have the same overall area of 650 square feet, which is equivalent to 60.38 square metres (JPN, 2006).

Several architectural improvements have been implemented in the TM design, which involve the external and internal design forms. In TM the living/dining area is smaller than in PHP 2000 to allow foyer space in front of the main entrance. This space has a similar position to the serambi in a Malay house to promote interaction between neighbourhoods. The other improvement in TM is a larger yard space than in PHP 2000. This is because in PHP 2000, the yard design is too small and located too far from the exposed area, which leads to insufficient space for a clothes-drying area. On the other hand, the separation of the toilet and bathroom in PHP 2000 means the toilet size becomes too small and uncomfortable. In TM, both facilities are located in the same space; thus it creates better movement of the occupant and air.

Because the humidity is high, air movement is crucial to help perspiration to evaporate (Bureau of Meteorology, 2012). Hence, TM has been designed with windows opposite each other, a narrow floor plan and ventilation openings such as top and bottom louvers to allow air movement. The complicated wall arrangements in PHP 2000 reduce the cross ventilation that flows from the front to rear façade. In TM, cross ventilation is achieved with a parallel arrangement of windows as well as the placement of high louvers on the internal walls, as shown in Figure 5. Furthermore, overhangs are placed on top of the windows to provide protection from sunlight and rainfall. The width of the overhang in TM is $600 \mathrm{~mm}$ but none in PHP 2000. 

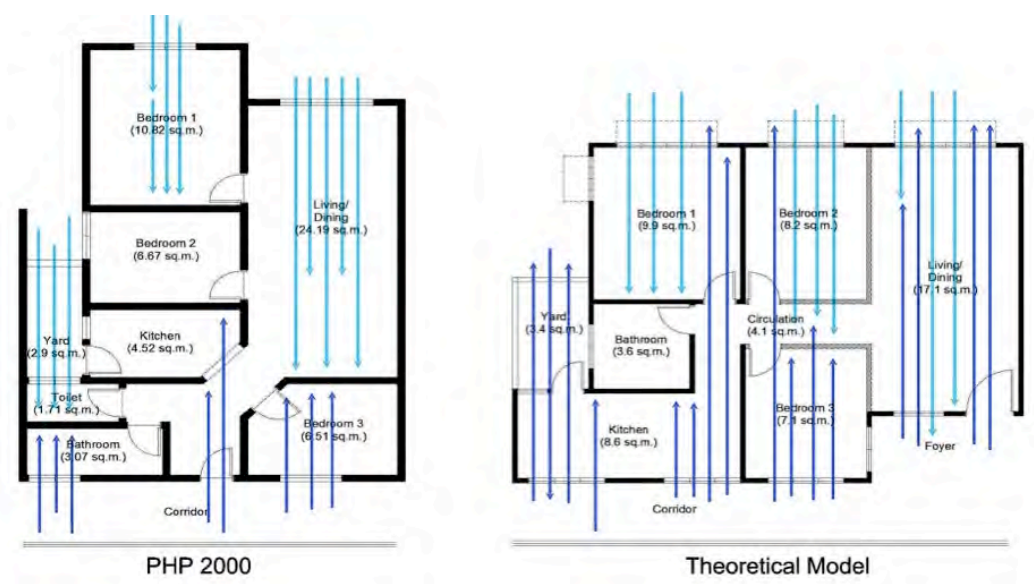

Figure 5. Comparison of Ventilation Flow of PHP 2000 and theoretical model (TM) (Source: Author)

Window design in a traditional Malay house is divided into three operable sections, which are top, middle and bottom. As shown in Figure 6, TM has 3.5 metre-high walls, and its external walls are divided into three sections. The sections are top louvers, windows and bottom louvers. In a Malay house design, some openings on the gable ends are placed to allow air movement. Thus, in TM, the same concept is translated through the placement of internal and external high louvers.

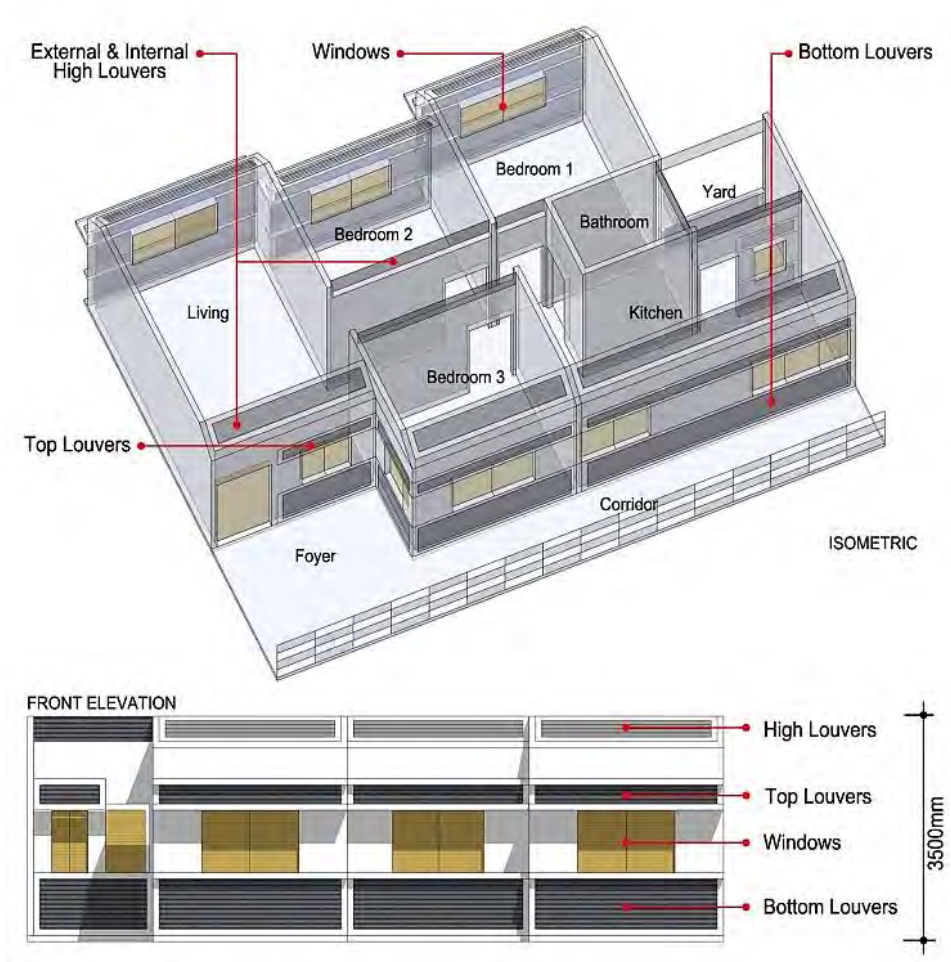

Figure 6: Placement of openings in theoretical model (TM) (Source: Author)

In a hot-humid climate, a lightweight structure performs better as it cools down rapidly (Saini, 1970: 25). Furthermore, 'materials with heat-storage capacity such as bricks and concrete have little benefit' (Bureau of Meteorology, 2012). In TM, lightweight materials such as a gypsum board with insulation is used for the external wall. Meanwhile, for the internal wall, plasterboard 
with insulation is the replacement for the conventional single brick wall. In a hot-humid climate, a thin insulation is preferable to bulk insulation, which is not desirable because it prevents the house cooling down at night (Bureau of Meteorology, 2012).

In conclusion, the TM design that has been applied with architectural and construction improvements has now become one of the new typologies for social housing in Malaysia. Therefore, the changes applied in TM should be tested and analyzed in IES <VE> software to assess their suitability. All the settings and simulation variables mentioned before will be used in order to provide a fair comparison.

\section{Results and Findings}

The main findings from the results are:

a) The mean air temperature in Malay houses and TM ranges from $25.2^{\circ} \mathrm{C}$ to $27.2^{\circ} \mathrm{C}$. This range can be considered the best air temperature in a naturally ventilated building in Malaysia.

b) The minimum relative humidity in Malay houses and TM ranges from $30 \%$ to $60 \%$. This range is achievable and therefore can be considered the preferred humidity range in a naturally ventilated building.

c) The mean internal ventilation in Malay houses and TM cases (except the dapur and serambi) ranges from 0.15 to $0.4 \mathrm{~m} / \mathrm{s}(150.0$ to $400.0 \mathrm{l} / \mathrm{s})$. Meanwhile, the external ventilation in Malay houses and TM (except the dapur) ranges from 0.30 to $1.45 \mathrm{~m} / \mathrm{s}$ (300.0 to $1450.0 \mathrm{l} / \mathrm{s})$. Thus, the preferred range of air ventilation in a naturally ventilated building is 0.30 to $1.50 \mathrm{~m} / \mathrm{s}$.

d) The external opening area in a Malay house is $15 \%$ to $20 \%$, while in $\mathrm{TM}$, the opening areas on the walls facing outside (open space) is $25 \%$ and the wall facing inside (corridor) is about $50 \%$. These percentages could be the best configuration of opening percentage in a naturally ventilated building.

e) The best carbon emission for a naturally ventilated building is $2571 \mathrm{kgC02} / \mathrm{year}$, and the energy consumption should not be more than $5.1963 \mathrm{MWh} /$ year.

The findings listed above are the initial parameters than can be used as the first Air House standard in Malaysia.

\section{'Air House' Standard for Naturally Ventilated Building in Malaysia}

Based on all the results defined in Malay houses and theoretical models, the proposed Air House design standard is listed in Table 4. The air temperature ranges from $25^{\circ} \mathrm{C}$ to $27^{\circ} \mathrm{C}$. The relative humidity for 'Air House' is $30 \%$ to $60 \%$. Meanwhile, the air movement is between 0.30 to $1.50 \mathrm{~m} / \mathrm{s}$. The total energy consumption for Air House standard is less than $5.0 \mathrm{MWh} / \mathrm{year}$ and less than $2500 \mathrm{kgC0} / \mathrm{year}$ for carbon emission.

Table 4: The initial design conditions of 'Air House' for naturally ventilated building (Source: Authors)

\begin{tabular}{|l|l|l|}
\hline Recommended Air Temperature & $25^{\circ} \mathrm{C}-27^{\circ} \mathrm{C}$ & $77.0^{\circ} \mathrm{F}-80.6^{0} \mathrm{~F}$ \\
\hline Recommended Design Relative Humidity & $30 \%-60 \%$ & $300.0 \mathrm{I} / \mathrm{s}-1500.0 \mathrm{l} / \mathrm{s}$ \\
\hline Recommended Air Movement & $0.30 \mathrm{~m} / \mathrm{s}-1.50 \mathrm{~m} / \mathrm{s}$ & \multicolumn{2}{|l|}{} \\
\hline Energy Consumption & Less than $5.0 \mathrm{MWh} / \mathrm{year}$ \\
\hline Carbon Emission & \multicolumn{2}{|l|}{ Less than $2500 \mathrm{kgC0} / \mathrm{year}$} \\
\hline
\end{tabular}

Table 5 shows the design parameters for a naturally ventilated building in Malaysia. $15 \%$ to $25 \%$ of an opening area is recommended for an external wall that faces an open space, while for a wall covered by shade or facing another block, $25 \%$ to $50 \%$ of an opening area is recommended. As higher altitude provides higher velocity, the units located on the eleventh floor and above should have a smaller opening area than units on the first to tenth floors. Furthermore, to promote air movement and cross ventilation, the four components of opening in Air House that 
should be implemented are bottom louvers, windows, top louvers and high louvers. The proportionate rule of these openings is $2 \mathrm{x}: 2 \mathrm{x}: 1 \mathrm{x}: 1 \mathrm{x}$ relatively, as shown in Figure 7.

Moreover, the unit plan layout should be in proportion of $1.5 \mathrm{x}$ for walls parallel to the corridor, and $1 \mathrm{x}$ for walls perpendicular to the corridor (Figure 7 ). To provide shade from sun radiation and rainfall, the minimum overhang recommended is 0.6 metres, while to promote better air circulation around the building, breaks between units are recommended. In terms of material selection, Air House standard uses prefabricated, lightweight and low thermal mass materials for the walls, floor and roof components.

Table 5: 'Air House' design parameters for natural ventilated buildings in Malaysia (Source: Authors)

\begin{tabular}{|l|l|}
\hline \multicolumn{2}{|c|}{ 'Air House' Design Parameters } \\
\hline $\begin{array}{l}\text { Proportion of Opening Components (Bottom Louvres : } \\
\text { Windows : Top Louvers : High Louvres) }\end{array}$ & $2 \mathrm{x}: 2 \mathrm{x}: 1 \mathrm{x}: 1 \mathrm{x}$ \\
\hline $\begin{array}{l}\text { Opening Areas for Walls Facing Outside }\left(1^{\text {st }} \text { Floor to } 10^{\text {th }}\right. \\
\text { Floor) }\end{array}$ & $15 \%$ to $25 \%$ (from total external wall area) \\
\hline Opening Areas for Walls Facing Inside $\left(1^{\text {st }}\right.$ Floor to $10^{\text {th }}$ Floor) & $25 \%$ to $50 \%$ (from total external wall area) \\
\hline $\begin{array}{l}\text { Opening Areas for Walls Facing Outside }\left(11^{\text {th }} \text { Floor and }\right. \\
\text { above) }\end{array}$ & $10 \%$ to $20 \%$ (from total external wall area) \\
\hline Opening Areas for Walls Facing Inside $\left(11^{\text {th }}\right.$ Floor and above) & $20 \%$ to $45 \%$ (from total external wall area) \\
\hline $\begin{array}{l}\text { Proportion of Plan Unit Layout (Parallel Wall : Perpendicular } \\
\text { Wall) }\end{array}$ & $1.5 x: 1 x$ \\
\hline Range of Overhang's Depth & $0.6-1.0$ meter \\
\hline Breaks between Units & 2.0 meters \\
\hline Recommended Materials & Prefabricated, Lightweight and Low Thermal \\
& Mass \\
\hline
\end{tabular}
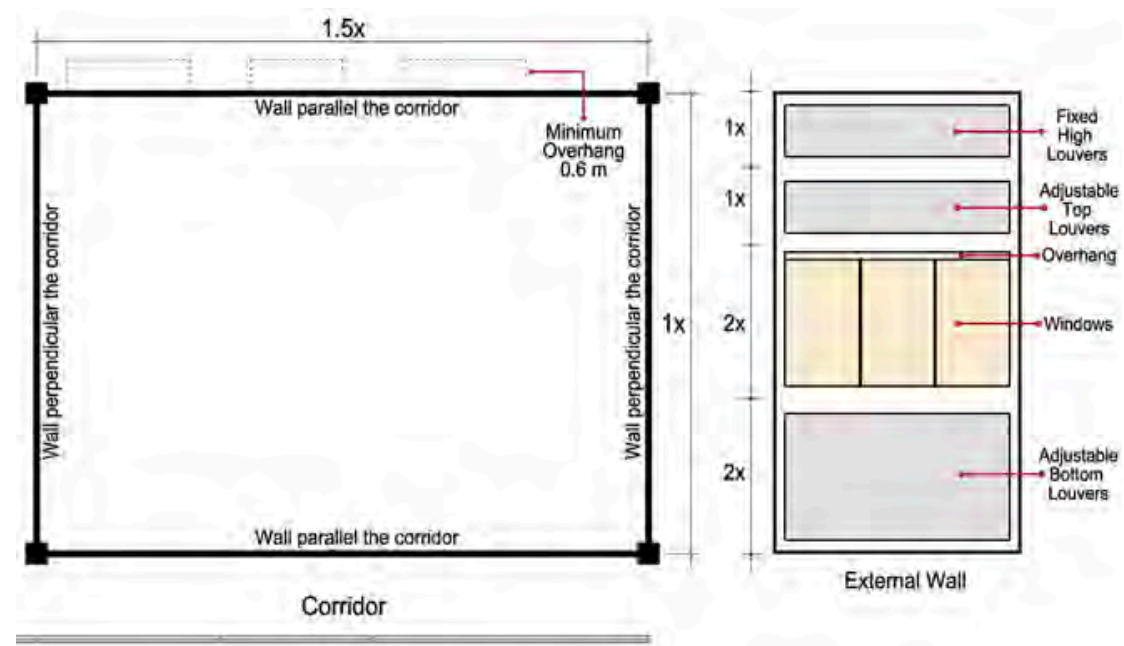

Figure 7: 'Air House' Design Parameters Diagram (Source: Author)

\section{Conclusions and Recommendations}

As a conclusion, there are some design issues discovered in traditional Malay houses and social housing. According to research, materials that are used in Malay houses are more practical and reliable for releasing heat readily, compared to high thermal capacity materials such as bricks and concrete in social housing. These high thermal materials store heat and cause uncomfortably high temperatures at night.

In a traditional Malay house, full-length openings are located at body level, while in modern housing the openings are smaller and only concentrate on the upper part of the body. 
Therefore, the cross ventilation process often fails in modern housing. Overhangs are important in opening components because they can provide shade for the walls from sun radiation, glare and rainfall. This key element is always neglected in modern housing.

For religious reasons, the orientation of a traditional Malay house normally faces Mecca or an east-to-west direction. This orientation, by coincidence, can reduce the external wall that faces direct sunlight. However, in modern housing, this orientation is not emphasized for profit motives. Moreover, the internal space arrangement in a traditional Malay house uses a front-to-back order where the serambi is the first area, followed by the rumah ibu and dapur. This arrangement preserves the privacy level of a Malay family and contributes to neighbourhood enhancement.

The results of the analysis of Malay houses and People's Housing Project (PHP 2000) show that the performance of air temperature and relative humidity in both cases were not significantly different. However, for internal and external air ventilation, the traditional Malay houses recorded $1,450.3 \mathrm{l} / \mathrm{s}(1.45 \mathrm{~m} / \mathrm{s})$ compared to just only $31.7 \mathrm{l} / \mathrm{s}(0.03 \mathrm{~m} / \mathrm{s})$ for PHP 2000 . The massive amount of air ventilation in Malay houses contributes to a better performance of the house thermally and economically.

The theoretical model has been developed and tested. The model has been improved according to the architectural and construction issues found in an actual PHP 2000. One of the major improvements is the proportionate rule of layout unit. Instead of a long and narrow layout, the theoretical model has a longer and wider layout where the external wall area is longer than PHP 2000; this promotes massive airflow in, out and across the house through the opening components.

Using the results obtained from the analyses, a standard called Air House has been defined. This standard is totally focused on natural ventilation strategies, in which air is designed to flow across the house compound. Meanwhile, in 'Passivhaus', the design is more about airtightness and isolation of heat within the house compound. The establishment of 'Air House' could perhaps be a new beginning for Malaysian architecture and its tropical region.

The hot temperature and high humidity climate in Malaysia encourages the use of an air conditioning system as the primary option to cool the house. Nowadays, this is the standard practice in Malaysia. An effort should be made to rectify this situation. The theoretical model that has been developed proves that there is a possible way to achieve the right thermal comfort by using passive methods in social housing. Therefore, this study answers the problem posed at the beginning of the study.

Upon completion of the study, it can be deduced that there is a huge gap between the traditional approach and modern housing. One of the reasons for this situation is the inappropriate regulations and standards being used in Malaysia. Therefore, some improvements and revisions should be made in order to meet the current challenges, as some of the regulations are not compatible with Malaysia's climate and culture.

In clauses 32, 33, 34 and 35 of Uniform Building By-Law (UBBL) Part III (space, light and ventilation), open spaces must be provided in residential building compounds. However, the categories listed are only related to buildings abutting a street, a back lane and a detached building; there is no category relating to linked units abutting a corridor in a multi-story building. According to the research findings, a common space in front of the main entrance is an important element in building a good, responsible society. Therefore, in theoretical model (TM), foyer space is provided to serve as interaction space as well as storage area. Thus, an improvement that can be compatible with local culture and the basic needs of the people should be made.

Clause 39 (1) states that residential buildings shall be provided with natural lighting and natural ventilation. The openings area is not less than $10 \%$ of floor area. For an example that follows the minimum requirement, a living/dining area in TM that has 19.6 square metres will have an area of window opening of less than 2.0 square meters. Based on the research findings, this percentage is too small for an opening to allow air movement. As TM has been proven to provide good air movement, clause 39 (1) should be revised to a new and more suitable percentage of opening area that is compatible with Malaysia's climate. 
In order to achieve thermal comfort through air movement, a large opening at the external and internal wall should be made. Therefore, $15 \%$ to $20 \%$ of external openings are required on an external wall for achieving suitable amount of air movement. Moreover, an opening at a high level of wall should be placed to allow ventilation and air change processes.

The window openings are suggested to be placed at body level range and must be $15 \%$ to $20 \%$ of a room's external wall. For internal partitions, fixed louvers could be placed on the top part of the partition to allow air transfer from room to room.

Moreover, in clause 42 (2), the minimum kitchen area in UBBL is 4.5 square metres and the minimum width is 1.5 metres. This measurement is still small and leads to insufficient space area. Therefore, the kitchen area should be revised to be at least 8.0 square metres and 2.0 metres minimum in width.

Finally, in clause 44 (1), the minimum height of a living room is 2.5 metres, while a kitchen is 2.25 metres. These heights are considered low and less efficient to promote air movement; thus, the minimum of 3.5 metres, as in TM's design, should be used in this clause.

The Air House concept that focuses on natural ventilation in residential buildings has proven it can reduce $86 \%$ of carbon emission and $74.3 \%$ of energy consumption compared to standard practice. The Air House concept has brought sustainable design in Malaysia to a new level of achievement; therefore, it should be explored and expanded in greater detail in the future.

Thermal comfort is one of the basic needs. However, in urban areas, thermal comfort becomes more crucial as houses are constructed in multi-level format with compact design. The concept of Air House could perhaps provide a new dimension in the design of comfortable and sustainable housing in the future.

\section{ACKNOWLEDGEMENT}

I would like to thank the various people and organisations whose help have made this research possible. The Center of Built in the Malay World (KALAM), Universiti Teknologi Malaysia (UTM) and KALAM's director, YM Dr. Raja Nafida Raja Shahminan, for her support and the contribution of study materials. John Brennan, Head of Architecture and Landscape Architecture (ESALA), The University of Edinburgh for his support and lecture notes.

This research was conducted in The University of Edinburgh, which also has been awarded to 'Andrew Grant Award' for the best dissertation for MSc. Advanced Sustainable Design in year 2012.

\section{REFERENCES}

Abd. Rahman, A. B., \& Omar, W. (2006). Issues and Challenges in the Implementation of Industrialised Building Systems in Malaysia. Presented at the Proceedings of the 6th Asia-Pacific Structural Engineering and Construction Conference (ASPEC 2006), Kuala Lumpur, Malaysia.

Bureau of Meteorology. (n.d.). Design Tips For the Hot Humid Climate. Australian Government. Retrieved July 24, 2012, from http://www.bom.gov.au/climate/environ/housedesign/HSWW_d.shtml

Center of Built in the Malay World (KALAM). (1986). Rumah Datuk Baginda Tan Mas Mohar (1850). Universiti Teknologi Malaysia.

Center of Built in the Malay World (KALAM). (1996). Rumah Andak Endah (1920). Universiti Teknologi Malaysia.

Chen, Y.-R., Ariffin, S. I., \& Wang, M.-H. (2008). The Typological Rule System of Malay Houses in Peninsular Malaysia. Journal of Asian Architecture and Building Engineering, (254).

Fisk, D. (1981). Comfort and Energy Consumption. The Architecture of Energy. New York: Longman Inc.

Goh, A. T., \& Ahmad, Y. (2011). Public Low-Cost Housing in Malaysia: Case Studies on PPR Low-Cost Flats in Kuala Lumpur. Journal of Design and the Built Environment, Volume 8.

Hanafi, Z. (1994). Housing Design in Relation to Environmetal Comfort - A Comparison of the Traditional Malay House and Modern Housing. Building Research and Information, Volume 22. 
Hassan, A. S., \& Ramli, M. (2010). Natural Ventilation of Indoor Air Temperature: A Case Study of the Traditional malay House in Penang. Science Publications, American J. of Engineering and Applied Sciences 3 .

Ismail, Z., \& Ahmad, A. S. (2006). Modularity Concept in Traditional Malay House (TMH) in Malaysia. Presented at the International Conference on Construction Industry, Universitas Bung Hatta, Indonesia.

KALAM. (2012). Center for the Study of Built Environment in the Malay World (KALAM). KALAM UTM: Pusat Kajian Alam Bina Dunia Melayu. Wordpress, . Retrieved June 19, 2012, from http://utmkalam.wordpress.com/author/utmkalam/

Lee, H. Y. (2003). The Kampong House: Evolutionary History of Peninsular Malaysia's Vernacular Houseform. Asia's Old Dwellings: Tradition, Resilience and Change (pp. 235-257). United States: Oxford University Press Inc.

Mohit, M. A., Ibrahim, M., \& Rashid, Y. R. (2010). Assessment of Residential Satisfactionin Newly Designed Public Low-Cost Housing in Kuala Lumpur, Malaysia. Habitat International, (34), 18-27.

National Housing Department, (2006). JPN Standard Plan 2000.

Saini, B. S. (1970). Architecture in Tropical Australia. Great Britain: Melbourne University Press.

Salih, K. (1982). Urban Dilemmas in Southeast Asia. Singapore Journal of Tropical Geography, Volume 3 (Issue 2).

United Nations Human Settlements Programme (UN-HABITAT). (2011). Affordable Land and Housing in Asia. Nairobi, Kenya: UNON, Publishing Services Section.

Yuan, L. J. (1987). The Malay House: Rediscovering Malaysia's Indigenous Shelter System. Pulau Pinang, Malaysia: Institut Masyarakat.

\section{NOTE}

This paper was presented in the $17^{\text {th }}$ International Conference on Sustainable Architecture and Urban Design (ICSAUD 2015 ) in Venice, Italy on $13^{\text {th }}-14^{\text {th }}$ of April 2015.

\section{AUTHORS}

\section{Mohd Firrdhaus Mohd Sahabuddin}

Postgraduate Student, Master of Science Advanced Sustainable Design (2011-2012)

The University of Edinburgh, School of Arts, Culture and Environment (ACE)

dosh212@gmail.com

\section{Cristina Gonzalez-Longo}

Lecturer in Architectural Heritage, Conservation and Community Identity

Department of Architecture, University of Strathclyde, Glasgow, United Kingdom

c.gonzalez-longo@strath.ac.uk 